\title{
A SUMMER TANAGER IN MANITOBA
}

JIM PURDY, Box 1029, Russell, Manitoba. R0J 1W0

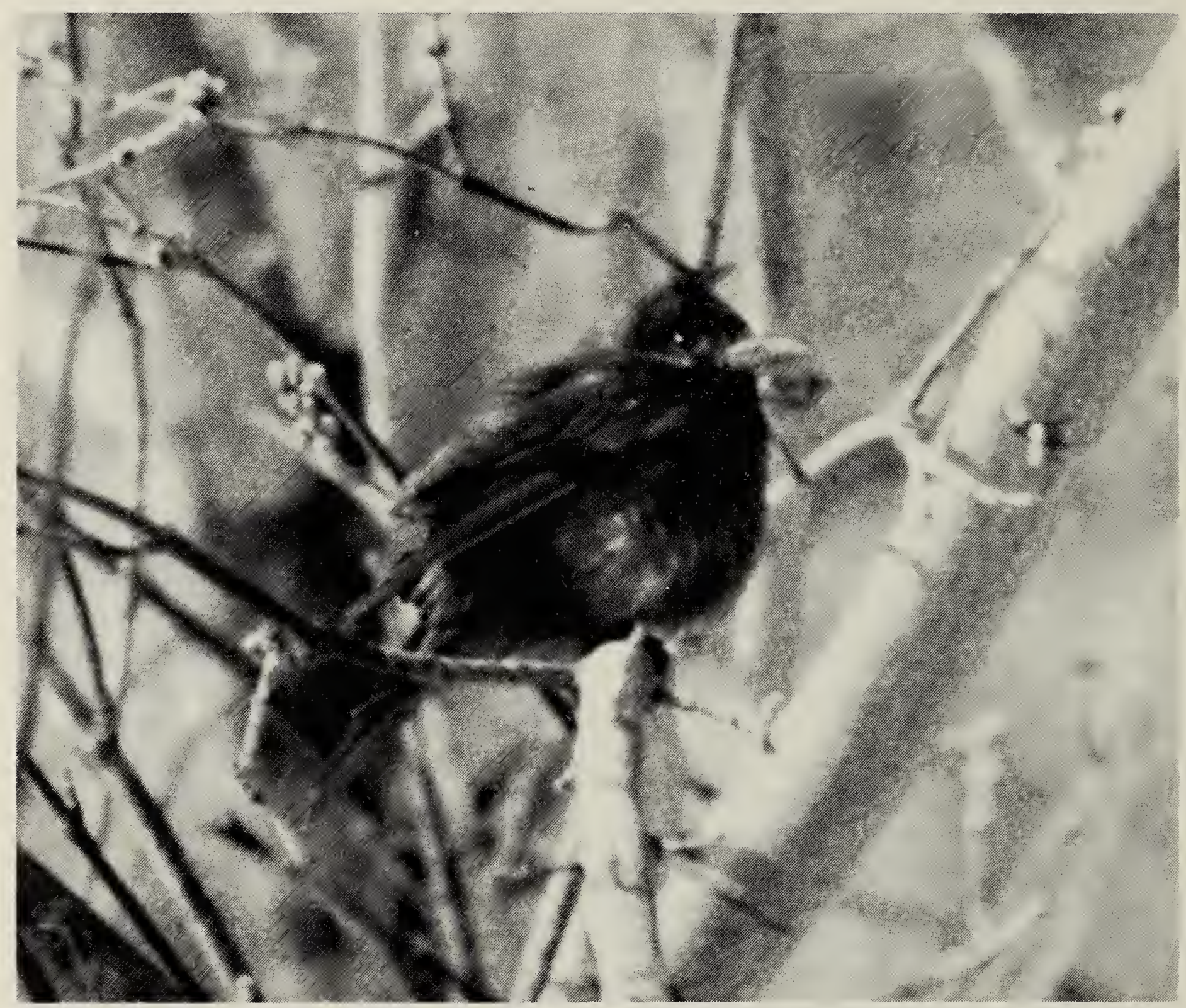

Male Summer Tanager, Silverton, Manitoba

R.F. Koes

On 2 April 1986 I sighted an unusual bird at the E \& V Dunn's Hereford Ranch, $5 \mathrm{mi}$. east and $3 \mathrm{mi}$. north of Russell, Manitoba. It was immediately recognised as a rare bird, so rare in fact, that the notation in my field notebook records the sighting simply as "new bird".

This "new bird" was about the size of an Evening Grosbeak, though perhaps somewhat smaller. The head, breast, and tail were rosy-red, possibly with a hint of black. The wings and back appeared dusky or dirty-red; the very tips of the wings may have been touched with black but nowhere on the bird were any black patches observed. The bill seemed longer and more slender than the grosbeak's and appeared medium in colour.

The bird was observed taking food from the surface of the snow and from bare patches of straw. These were seen, with the aid of binoculars, to be honey bees. Several years ago a hive of honey bees took up residence in the west-facing wall 
of Evin Dunn's house. On sunny, warm days, even in the midst of winter, activity was often observed around the nest entrance. As the snow melted in the spring, dead bees would become exposed on the snow and ground under the nest.

The bird was observed five times on 2 April, from $1730 \mathrm{~h}$ till $1830 \mathrm{~h}$ under good lighting conditions through $7 \times 35$ binoculars at an approximate distance of 40 feet. There had been strong easterly winds most of the day. The temperature was above freezing but cold.

Several possible identifications were quickly eliminated. The heavy, crossed bill of the crossbills as well as the black wings and tail of the Red Crossbill and the conspicuous white wing-bars of the White-winged Crossbill and Pine Grosbeak were lacking. The bird was a dull, not a bright red as in the Scarlet Tanager and the wings were not black; it also lacked the high crest and black bib of the Cardinal. All of these obvious alternatives, with the exception of the Cardinal, were familiar to the author. It was with great excitement that the identification of male Summer Tanager was contemplated.

This sighting was reported verbally on 2 April to Jim Spear, Sr., of Russell, a local, avid birder, and H.W.R. Copland of the Manitoba Museum of Man and Nature, Winnipeg.

On 7 April, the bird was again observed several times. From observations at 15 feet from it sitting on a fence, feeding on dead bees from the ground, and hawking flying insects (also presumed to be bees) there remained no doubt about the identification: male Summer Tanager. I observed the bird under various weather conditions and at different times of day, both alone or in the presence of Dark-eyed Juncos, Brewer's Blackbirds, Rusty Blackbirds or Evening Grosbeaks on 2, 7, 8, 9, 11, and 12 April.
This bird was seen by at least 17 people, including Jim Spear, Sr., and Jim Spear, Jr., both of Russell, on 5 April; Jean Horton, Hazel Patmore, and Edith Kerr, all of Brandon, on 9 April; Rudolf Koes and Russell Tkachuk of Winnipeg and Norman and Donna Short of Rivers, on 12 April. Koes, Tkachuk and Short took numerous photographs to verify and document this sighting. The latter also managed extensive footage on video of the Summer Tanager sunning itself on the roof and eves of the house and catching and eating insects.

The last recorded sighting of the tanager was made by me in the early evening of 12 April. Unsuccessful attempts to sight the bird were made by Bill Walley of Dauphin on 13 April and Cal Cuthbert of Brandon on 16 April. Cuthbert's unproductive endeavor led him to speculate that the tanager may have succumbed to the elements. However, an unconfirmed sighting made by Larry Chuckree, $3 \mathrm{mi}$. south-west of the Dunn farmstead was reported to Jim Spear, Sr., on 3 May. I attempted to follow this lead and though Chuckree's verbal description corresponded to the Summer Tanager, no further sightings had been made at the time of this writing.

Range maps indicate that the eastern and southern United States are the normal distribution for this species. ${ }^{8}$ Godfrey includes the Summer Tanager in the 1986 revision of "Birds of Canada" as casual in eastern Canada and accidental in Manitoba and Saskatchewan. ${ }^{3}$

The "Manitoba birds field check-list" includes the Scarlet Tanager as occurring regularly and the Western Tanager as occurring irregularly in Manitoba. No mention is made of the Summer Tanager. ${ }^{1} \mathrm{Un}$ fortunately, this list does not include every species that has been reported in the province. Previous documented sightings of the Summer Tanager within Manitoba are as follows: 
- 28 May 1953, one male, 11 mi. n.e. of Portage la Prairie, sight record by Mrs. Norman Cuthbert and family ${ }^{6}$

- 24 May 1966, one first year male, Woodlands, R. Langrell, specimen in Manitoba Museum of Man and Nature $^{9}$

- 25 May 1966, one immature male, found dead on Rahl's Island in the Saskatchewan River near The Pas, Harvey Anderson, specimen in Sam Waller's Little Northern Museum²

- 11, 13-18 November 1978, one specimen, Selkirk, Mr. \& Mrs. W.W. Sargent, died 18 November, specimen in Manitoba Museum of Man and Nature $^{9}$

- 13 June 1981, one pre-adult male found dead, near Brandon, specimen in B.J. Hales Museum, Brandon ${ }^{9}$

- 14-15 June 1983, one banded individual, Delta, S.G. Sealy 4

- 19-27 May 1984, one adult male, $n$. of Birds Hill Provincial Park, G. \& J. Lowden and others, photographed. ${ }^{5}$

A.C. Bent notes that the feeding habits of the Summer Tanager have not been thoroughly studied, but it has been observed as an avid eater of bees and wasps. It has been seen catching bees out of the air and is often considered a pest in and around apiaries. ${ }^{10}$ Martin, et al. confirm the lack of information available on the food habits but note an almost exclusive diet of insects. ${ }^{7}$ My observations concur with Bent and Martin's tentative conclusions regarding the feeding habits of the Summer Tanager.

In the 12 years that I have been actively birding in western Canada, this sighting of the male Summer Tanager has been my most exciting and rewarding experience.

\section{Acknowledgements:}

I wish to express my gratitude to Rudolf Koes for his critical review of this manuscript and especially for supplying the list of provincial sightings.

1 ANONYMOUS. 1979. Manitoba birds, field check-list (revised). Man. Mus. of Man and Nature, Winnipeg.

2 GOdFREY, W.E. 1966. A Summer Tanager in Manitoba. Can. Field-Nat. 80:254.

3 GODFREY, W.E. 1986. The birds of Canada: revised edition. Nat. Mus. of Canada, Ottawa.

${ }^{4}$ GOLLOP, J.B. 1983. The nesting season: Prairie Provinces Region. American Birds 37:999.

5 GOLLOP, J.B. 1984. The spring migration: Prairie Provinces Region. American Birds 38:927.

${ }^{6}$ LAWRENCE, A.G. 1953. Chickadee notes No. 1678. Winnipeg Free Press, 17 July 1953.

7 MARTIN, A.C., H.S. ZIM and A.L. NELSON. 1961. American wildlife and plants: a guide to wildlife food habits. Dover Publ. Inc., New York.

8 ROBBINS, C.S., B. BRUUN and H.S. ZIM. 1983. Birds of North America (expanded and revised). Golden Press, New York.

9 ROUNDS, R.C. 1981. New record of a Summer Tanager in Manitoba. Blue Jay 39:225.

10 TERRES, J.K. 1980. The Audubon Society encyclopedia of North American birds. Alfred A. Knopf, New York. 